\title{
Optimized Quantification of Unculturable Candidatus Liberibacter Spp. in Host Plants Using Real-Time PCR
}

\begin{abstract}
Wenbin Li, National Plant Germplasm and Biotechnology Laboratory, United States Department of AgricultureAnimal and Plant Health Inspection Service (USDA-APHIS)-PPQ-CPHST, Beltsville, MD 20705; Dayan Li, Harvard University, Cambridge, MA 02138; Elizabeth Twieg, National Plant Germplasm and Biotechnology Laboratory, USDA-APHIS-PPQ-CPHST; John S. Hartung, USDA-Agricultural Research Service, Molecular Plant Pathology Laboratory, Beltsville, MD 20705; and Laurene Levy, National Plant Germplasm and Biotechnology Laboratory, USDA-APHIS-PPQ-CPHST
\end{abstract}

\begin{abstract}
Li, W., Li, D., Twieg, E., Hartung, J. S., and Levy, L. 2008. Optimized quantification of unculturable Candidatus Liberibacter spp. in host plants using real-time PCR. Plant Dis. 92:854-861.

Citrus huanglongbing (HLB) is caused by the phloem-limited and psyllid-vectored Candidatus Liberibacter spp. and is a destructive disease of citrus that is rapidly increasing in importance. The disease was reported recently in the principle citrus-producing areas of São Paulo, Brazil in 2004 and in Florida in 2005. A variety of laboratory methods have been developed to confirm a symptom-based disease diagnosis or for the detection or identification of the pathogen; however, no quantitative information has been available on the pathogen titer in either host or vector interactions because the pathogen remains unculturable in artificial media. We previously developed a quantitative polymerase chain reaction (PCR)-based assay for detection of $\mathrm{Ca}$. Liberibacter spp. and, in this study, we evaluated the effects of sample composition on quantification of the pathogen in citrus plants by TaqMan real-time PCR. Standard curves were established using cloned plasmids containing target DNA from the pathogen and with total DNA samples from field-grown HLB-infected citrus plants. Regression analysis showed that a standard curve established with DNA extracted from naturally infected field-grown plants was more accurate than the standard curve constructed from plasmids containing the amplification targets as cloned inserts. Nontarget DNA and putative PCR inhibitors from citrus plants decreased the sensitivity and the amplification efficiency of real-time PCR when plasmids provided the template target in "spiked" healthy citrus DNA extracts. This effect varied among plant tissue types, citrus species, and geographic locations. Based on these sample effects, a universal standard curve has been established for quantification of the pathogen in various citrus tissues of different citrus species planted in different geographic locations. Sample storage at $4{ }^{\circ} \mathrm{C}$ for 2 months prior to PCR assay did not affect subsequent quantification of the pathogen. The validated quantitative real-time PCR method and the universal standard curve will be very useful for studies of host-pathogen interactions and epidemiology, and in the development of control strategies for the disease.
\end{abstract}

Additional keywords: citrus greening, sweet orange

Citrus huanglongbing (HLB), also known as citrus greening, is a destructive, century-old disease of citrus $(2,5,8)$ caused by phloem-limited bacteria belonging to Candidatus Liberibacter spp. (13). The pathogen is transmitted by the psyllids Trioza erytreae in Africa (27) and Diaphorina citri in Asia and the Americas $(26,38)$. The pathogen also is transmitted by contaminated plant materials used for propagation of trees (3). Three Candidatus

Corresponding author: Wenbin Li

E-mail: Wenbin.Li@aphis.usda.gov

Accepted for publication 15 January 2008.

doi:10.1094/PDIS-92-6-0854

(C) 2008 The American Phytopathological Society in host samples usually is performed by counting CFU grown on a plate containing an artificial medium. Such traditional culture-based methods cannot be used for $\mathrm{Ca}$. Liberibacter spp. because none of the Candidatus spp. of Liberibacter has been cultured. DNA-based techniques can circumvent this obstacle.

Real-time polymerase chain reaction (PCR) has been used to quantify bacterial pathogens of humans, such as Enterobacter sakazakii (23), Salmonella spp., and Escherichia coli O157:H7 (16); of animals (e.g., Mycobacterium avium subsp. paratuberculosis) (33); and of plants, as was done for Xylella fastidiosa (21). In order to quantify the target DNA in a mixed sample and to determine the sensitivity of real-time PCR, a standard curve usually is established based on serial dilutions in water of either a reference DNA sample or a plasmid DNA containing the target DNA (32). The sensitivity of the assay based on such a standard curve might be different from one obtained with actual samples, which contain nontarget DNA and potential PCR inhibitors $(16,35)$. In addition, the standard deviation of the cycle threshold $(\mathrm{Ct})$ values in real-time PCR usually is higher when small amounts of target DNA are present, indicating a higher risk of errors in quantification at lower target DNA concentrations (23).

These sample composition effects reflect the reality that the quality of yield and purity of DNA extracts, host inhibitors, and preparation errors affect the results of the assay (16). We determined previously that the DNeasy Plant Kit (Qiagen, Valencia, CA) was the best method for DNA extraction and amplification of pathogens from citrus plants (18). Inhibitors from citrus plant tissues affect DNA amplification in conventional PCR assays $(9,14,18)$. To monitor the sample composition effects, we developed an internal amplification control for multiplex real-time PCR assays (19). Based on systematic comparisons among a uniform and extensive set of plant samples using the internal control (20), our multiplex real-time PCR was 
about 100-fold more sensitive than published conventional PCR and the LAMP assays $(11,14,30,38)$.

The objective of this study was to evaluate the effects of sample composition and prior storage of the samples on population estimates of ' $\mathrm{Ca}$. Liberibacter asiaticus' in host plant tissues. Our results indicate that the sensitivity of a real-time PCR assay could be overestimated and the target population could be underestimated in field-grown plant samples when the standard curve was established based on serial dilutions of target DNA in water compared with a standard curve established based on dilutions of the target DNA with a DNA extract from healthy field-grown samples. This improved method for quantification of $C a$. Liberibacter spp. will be very useful for revealing the bacterial population thresholds for acquisition and transmission by insect vectors, for survival of the pathogens in planta and in insect vectors, and for induction of disease symptoms. This information is greatly needed for management of the disease.

\section{MATERIALS AND METHODS}

Liberibacter strains and plant materials. DNA of ' $\mathrm{Ca}$. Liberibacter asiaticus' strains was isolated from midribs of HLBsymptomatic samples of pumelo, Citrus maxima (Burm.) Merrill. The samples were collected on 1 September 2005 by the Florida Department of Agriculture and Consumer Services in Homestead, FL and contained a high population of the pathogen (19). Unused portions of these HLBpositive plant materials were stored as whole leaves and chopped midribs in plastic bags at $4{ }^{\circ} \mathrm{C}$ to determine if prolonged cold storage affected subsequent detection and quantification of the pathogen.

Twigs, leaves, fruit, seed, and roots of field-grown suspect liberibacter-infected citrus plants were received from Florida, Texas, Georgia, Hawaii, and Puerto Rico. These samples were sent to us for testing because the plants had symptoms that could be caused by liberibacters. However, they were tested and shown to be negative for $\mathrm{Ca}$. Liberibacter spp. by conventional and real-time PCR assays (data not shown). These extracts of field-grown plants subsequently were used as healthy plant extracts. Samples from healthy greenhouse-grown citrus plants were also collected from the greenhouses of the United States Department of AgricultureAnimal and Plant Health Inspection Service (USDA-APHIS) and USDA-Agricultural Research Service (ARS), Beltsville, MD and used to prepare healthy plant extracts.

DNA isolation. Total DNA was isolated using the DNeasy Plant Mini kit (Qiagen) from $200 \mathrm{mg}$ of plant tissues and was suspended in $200 \mu \mathrm{l}$ of Tris-EDTA (TE) buffer (10 mM Tris-HCl, 1 mM EDTA, pH 8.0). Total DNA samples were also kindly pro- vided by Dr. Diva C. Teixeira (Fundecitrus, São Paulo, Brazil). These were prepared using a cetyltrimethylammonium bromide method (28) from $500 \mathrm{mg}$ of midribs from healthy field-grown sweet orange trees. Genomic DNA was extracted from strain Mach1-T1 of E. coli (Invitrogen, Carlsbad, CA) grown in Luria-Bertani broth using a Qiagen kit (Qiagen). DNA concentration in extracts was estimated with a SPECTRA max PLUS384 spectrophotometer (Molecular Devices, Sunnyvale, CA), and adjusted to $50 \mathrm{ng} / \mu \mathrm{l}$ with TE buffer.

Plasmid standard for quantification. A 1,160-bp ' $C a$. Liberibacter asiaticus' $16 \mathrm{~S}$ ribosomal DNA (rDNA) fragment was amplified from a field DNA sample from Florida with primer set OI1/OI2c (14) using the validated conventional PCR protocol (20). The DNA fragment was cloned into the TOPO TA pCRII vector (Invitrogen) and plasmids were propagated in the strain Mach1-T1 of E. coli (Invitrogen) and purified using a PureLink Quick Plasmid Miniprep kit (Invitrogen). The concentration of the plasmid DNA was estimated as above.

The 16S rDNA fragment was confirmed to be from ' $\mathrm{Ca}$. Liberibacter asiaticus' by sequencing at the Center for Biosystems Research, DNA Sequencing Facility, University of Maryland, College Park. The cloned plasmid was named pFL136. The number of copies of pFL136 per microliter was estimated from its known number of base pairs $(n=5,133)$ and the average molecular mass of a base pair in doublestrand DNA (660 Da). One copy (molecule) of pFL136 is $5.655 \times 10^{-6} \mathrm{pg}$. The initial concentration of the pFL136 stan- dard was adjusted in TE buffer to be $10^{10}$ copies/ $\mu$ l.

Ten-fold serial dilutions $\left(10^{10}\right.$ to 1 copy/ $\mu \mathrm{l})$ of $\mathrm{pFL} 136$ were prepared in triplicate using water, purified $E$. coli DNA in TE buffer at $50 \mathrm{ng} / \mu \mathrm{l}$, and total DNA extract from tissues of healthy citrus plants at $50 \mathrm{ng} / \mu \mathrm{l}$ as diluent to establish standard curves. Similarly, 10-fold serial dilutions of the field DNA extract obtained from midribs of $C$. maxima infected with ' $C a$. Liberibacter asiaticus' were prepared in triplicate using water, E. coli DNA at 50 $\mathrm{ng} / \mu \mathrm{l}$, and total DNA extract from healthy citrus plants at $50 \mathrm{ng} / \mu \mathrm{l}$ to establish standard curves. Finally, the liberibacterinfected $C$. maxima DNA extracts also were diluted in DNA extracts $(50 \mathrm{ng} / \mu \mathrm{l})$ from various tissues of healthy plants of different citrus species and in total DNA extracts $(50 \mathrm{ng} / \mu \mathrm{l})$ from healthy sweet orange midribs received from different geographic locations.

Real-time PCR. TaqMan real-time PCR assays with the target primer-probe set HLBaspr and the positive internal control primer-probe set COXfpr (citrus mitochondrial cytochrome oxidase) were performed as reported previously (18) in a SmartCycler II (Cepheid, Sunnyvale, CA). All reactions were performed in duplicate and each run contained one negative and one positive control.

Statistical analysis. Real-time PCR data were exported from the SmartCycler software (version 2.0D; Cepheid) for calculation of mean $\mathrm{Ct}$ values and standard deviations (SDs). Standard linear regressions $(Y=a+b X)$ of the $\log$ concentration of the target DNA copies $(Y)$ versus the

Table 1. Development of absolute standard curves for real-time polymerase chain reaction (PCR) detection of 'Candidatus Liberibacter asiaticus' DNA based on serial dilutions of cloned plasmid DNA (pFL136) in three diluents ${ }^{t}$

\begin{tabular}{|c|c|c|c|}
\hline \multirow[b]{2}{*}{ Molecules ${ }^{v}$} & \multicolumn{3}{|c|}{ Cycle threshold $(\mathrm{Ct})$ values $^{\mathrm{u}}$} \\
\hline & $\mathbf{X} \mathbf{w}^{\mathbf{w}}$ & $\mathbf{X e}^{\mathrm{x}}$ & $\mathbf{X c}^{\mathbf{y}}$ \\
\hline 10 & $14.59 \pm 0.18$ & $14.88 \pm 0.16$ & $14.46 \pm 0.17$ \\
\hline 9 & $16.61 \pm 0.20$ & $18.17 \pm 0.21$ & $18.04 \pm 0.19$ \\
\hline 8 & $18.07 \pm 0.19$ & $21.30 \pm 0.18$ & $21.20 \pm 0.20$ \\
\hline 7 & $21.60 \pm 0.23$ & $24.59 \pm 0.25$ & $24.48 \pm 0.24$ \\
\hline 6 & $24.13 \pm 0.21$ & $28.12 \pm 0.24$ & $27.92 \pm 0.26$ \\
\hline 5 & $27.55 \pm 0.25$ & $31.42 \pm 0.31$ & $31.43 \pm 0.32$ \\
\hline 4 & $30.94 \pm 0.28$ & $34.74 \pm 0.33$ & $34.24 \pm 0.35$ \\
\hline 3 & $34.02 \pm 0.30$ & $37.62 \pm 0.40$ & $36.58 \pm 0.42$ \\
\hline 2 & $37.15 \pm 0.50$ & $38.89 \pm 0.70$ & $39.42 \pm 0.75$ \\
\hline 1 & $39.06 \pm 0.68$ & Undetectable & Undetectable $^{\mathrm{z}}$ \\
\hline Mean $\Delta \mathrm{Ct}$ & 2.72 & 3.00 & 3.12 \\
\hline
\end{tabular}

${ }^{\mathrm{t}}$ The three dilution methods were water, Escherichia coli DNA at $50 \mathrm{ng} / \mu \mathrm{l}$, and plant total DNA extract at $50 \mathrm{ng} / \mu \mathrm{l}$. Regression analysis equations for each were water: $Y_{\text {aw }}=14.60-0.3445 X_{\text {aw }}, r^{2}=$ 0.9939 , and amplification efficiency $\left(\mathrm{AE} ; 10^{- \text {slope }}-1\right)=1.1878 ;$ E. coli DNA: $Y_{\text {ad }}=14.80-0.3172 X_{\text {ad }}$, $r^{2}=0.9945$, and $\mathrm{AE}=1.0893$; and plant total DNA extract: $Y_{\mathrm{am}}=14.74-0.3174 X_{\mathrm{am}}, r^{2}=0.9970$, and $\mathrm{AE}=1.0893$.

" $\mathrm{Ct}$ values of real-time PCR with different dilution media are means \pm standard deviation.

${ }^{v}$ Molecules of pFL136 per reaction $(\log )(\mathrm{Y})$. Mean = the mean Ct gradient between two 10-fold dilutions.

${ }^{\mathrm{w}}$ Water.

${ }^{x}$ Pure DNA from E. coli $(50 \mathrm{ng} / \mu \mathrm{l})$. Total DNA was extracted from pure culture of E. coli strain Mach1-T1 (Invitrogen, Carlsbad, CA).

${ }^{y}$ DNA extract from Citrus sinensis (50ng/ $\left.\mu \mathrm{l}\right)$. Total DNA was extracted from midribs of healthy sweet orange leaves.

${ }^{\mathrm{z}}$ Amplification was stopped at 50 cycles. 
mean $\mathrm{Ct}$ values $(X)$ were obtained. PCR amplification efficiency (AE) was calculated from the slopes of the standard curves using the equation $\mathrm{AE}=10^{\text {-slope }}-1$ $(1,10)$. If necessary, analysis of variance was performed on the means of $\mathrm{Ct}$ values and, when significant, this was followed by a means comparison test (Tukey's) using a confidence level of $P=0.05$.

\section{RESULTS}

Absolute standard curves. Three absolute standard curves were established using serial dilutions of the cloned plasmid pFL136 standard in water, or in a 50-ng/ $\mu \mathrm{l}$ solution of E. coli DNA, or in a total DNA extract $(50 \mathrm{ng} / \mu \mathrm{l})$ from midribs of healthy sweet orange (Table 1; Fig. 1). The accuracy of real-time PCR assays was high $\left(r^{2}\right.$ $>0.99$ ) for all three diluents based on linear regression analysis. The standard deviation of the mean $\mathrm{Ct}$ values tended to increase with increasing dilution of the target extracts, as would be expected. The precision of the assays was high $(\mathrm{SD}<$ 0.50 cycles) for all three diluents when 100 copies $(0.5655 \mathrm{fg})$ or more of the plasmid DNA was used per reaction. The PCR AE was similar for all three dilution methods.
However, the detection sensitivity was 10 -fold greater for serial dilutions of plasmid pFL136 DNA in water than for dilutions of pFL136 in pure E. coli DNA at 50 $\mathrm{ng} / \mu \mathrm{l}$ or in total DNA extract from midribs of healthy sweet orange at $50 \mathrm{ng} / \mu \mathrm{l}$ (Table $1)$. The limit of detection of the real-time PCR was 10 copies $(0.05655 \mathrm{fg})$ per reaction for the serial dilutions of pFL136 DNA in water. The limit of detection for the serial dilutions made in pure $E$. coli DNA at $50 \mathrm{ng} / \mu \mathrm{l}$ and in total DNA extract from midribs of healthy sweet orange at 50 $\mathrm{ng} / \mu \mathrm{l}$ was the same, at 100 copies $(0.5655$ fg) of the target plasmid DNA per reaction. The upper detection limit of the real-time PCR for all three dilution methods was the same at up to $10^{11}$ copies $(0.5655 \mu \mathrm{g})$ of the cloned plasmid pFL136 DNA per reaction (data not shown).

The PCR AE was $9.85 \%$ higher when the pFL136 DNA was diluted in water than when either E. coli DNA at $50 \mathrm{ng} / \mu \mathrm{l}$ or total DNA extract from the midribs of healthy sweet orange at $50 \mathrm{ng} / \mu \mathrm{l}$ was used as the diluent. There was no difference in PCR AE between the latter two dilution methods. The mean Ct gradients between two 10-fold dilutions for the absolute standard curves were $2.72,3.00$, and 3.12 for the serial dilu- tions of the plasmid DNA prepared in the three diluents (Table 1; Fig. 1).

Sample standard curves. Three standard curves were prepared from a single field DNA sample obtained from midribs of HLB-symptomatic $C$. maxima leaves collected in Florida. The log of the concentration of the target DNA in the sample was 6.2024 , which was estimated through the absolute standard curve $Y_{\mathrm{am}}=14.74-$ $0.3174 X$ (Table 1). The log concentrations of 10-fold serial dilutions of the field DNA sample then were 6.2024, 5.2024, 4.2024, 3.2024 , and 2.2024, respectively (Table 2).

There were no differences in the lower detection limit of real-time PCR for the field DNA sample among the serial dilutions prepared in water, E. coli DNA solution at $50 \mathrm{ng} / \mu \mathrm{l}$, and DNA extract from citrus plants at $50 \mathrm{ng} / \mu \mathrm{l}$ (Table 2; Fig. $1 \mathrm{D}$ F). The detection limit was $2.2024 \log$ $\left(1.59 \times 10^{2}\right)$ copies of the target DNA per reaction. The assay accuracy for the serial dilutions of the field DNA sample in the DNA extract from sweet orange was as high $\left(r^{2}>0.99\right)$ as for those dilutions in water and $E$. coli DNA solution at 50 $\mathrm{ng} / \mu \mathrm{l}$. However, PCR AE for the serial dilutions in DNA extract from healthy sweet orange was 7 to $8 \%$ lower than the
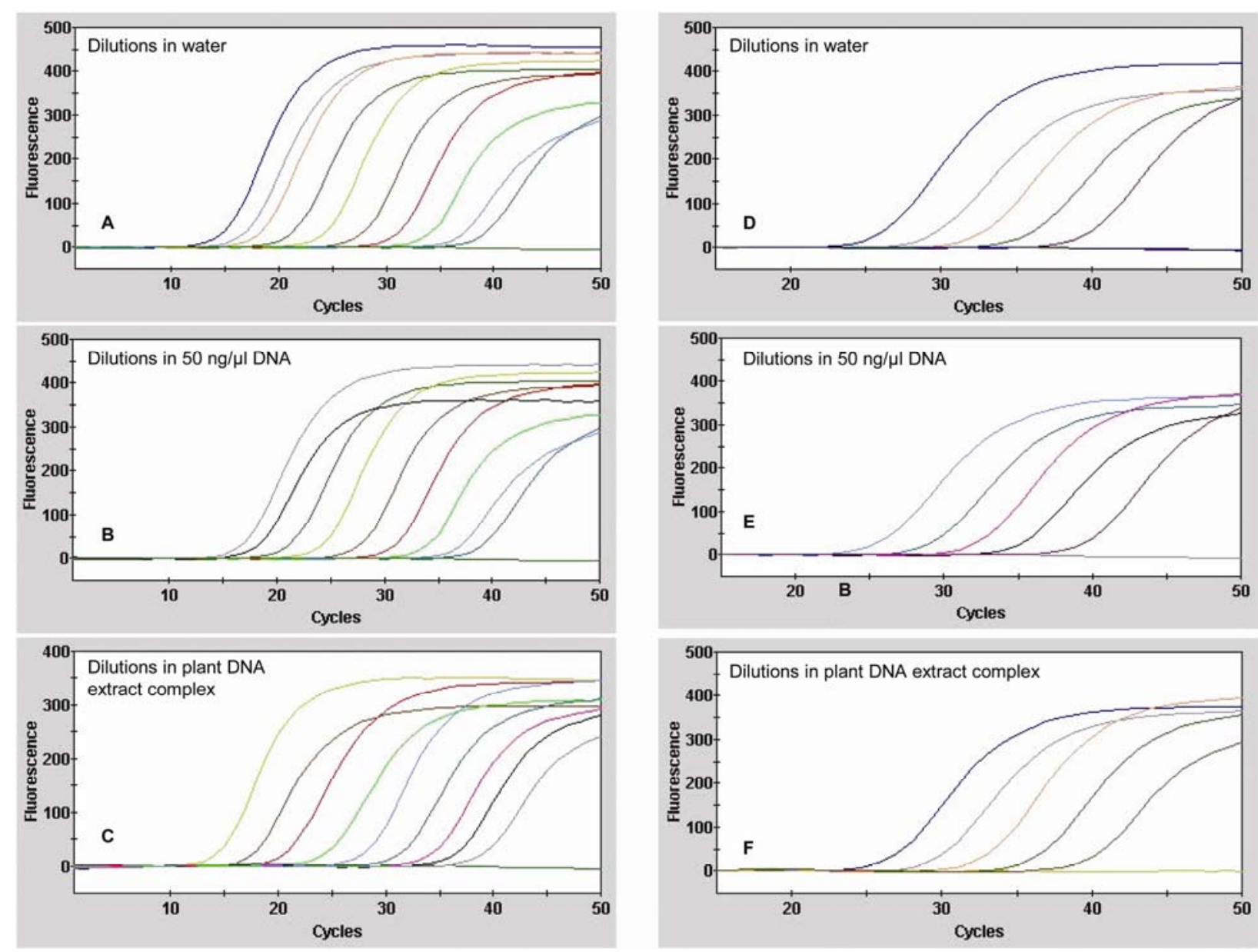

Fig. 1. Real-time polymerase chain reaction graphical display for serial dilutions ( $10^{10}$ to $10^{1}$ copies) of 'Candidatus Liberibacter asiaticus' target DNA. Tenfold serial dilutions were made in $\mathbf{A}$ and $\mathbf{D}$, water; $\mathbf{B}$ and $\mathbf{E}$, of Escherichia coli DNA at $50 \mathrm{ng} / \mathrm{\mu l}$; and $\mathbf{C}$ and $\mathbf{F}$, of total DNA extract from midrib of healthy sweet orange at $50 \mathrm{ng} / \mu \mathrm{l}$. A-C, The target was provided by plasmid FL136 containing the 16S rDNA fragment from 'Ca. Liberibacter asiaticus.' D-F, The target 16S rDNA was present in extracts of naturally infected leaf midribs from Citrus maxima. 
$\mathrm{AE}$ for the serial dilutions in water and $E$. coli DNA solutions at $50 \mathrm{ng} / \mu \mathrm{l}$. There were no differences in assay precision (SD of the mean $\mathrm{Ct}$ values) among three dilution methods.

Absolute versus sample standard curves. The estimated log concentrations of the target DNA in the field sample in Table 2 were transformed to the estimated target DNA copy number in the serial dilutions in Table 3. The estimates of target DNA copy number $(Y)$ were obtained with the regression equations $Y_{\mathrm{aw}}, Y_{\mathrm{ad}}$, and $Y_{\mathrm{am}}$ (regression with absolute standard curves; Table 1), and $Y_{\mathrm{sw}}, Y_{\mathrm{sd}}$, and $Y_{\mathrm{sm}}$ (regression with sample standard curves; Table 2), using the $\mathrm{Ct}$ values $(X)$ obtained from the serial dilutions of the target DNA (field sample) in total DNA extract from midribs of healthy sweet orange at $50 \mathrm{ng} / \mu \mathrm{l}$ (Table 2 ). The estimated deviation (ED) of the target DNA copy number was calculated using the equation $\mathrm{ED}=($ estimated value standard value)/standard value $\times 100(\mathrm{Ta}-$ ble 3), where the "standard value" is known from the formula molecular weight of the target and the mass of DNA added to the sample, and the "estimated value" is

Table 2. Development of relative standard curves for real-time polymerase chain reaction (PCR) detection of 'Candidatus Liberibacter asiaticus' DNA using DNA derived from a field sample obtained from an infected sweet orange plant from Florida and diluted in three diluents ${ }^{\mathrm{s}}$

\begin{tabular}{lcccc}
\hline & & \multicolumn{3}{c}{${\text { Cycle threshold }(\mathbf{C t}) \text { values }^{\mathbf{t}}}$} \\
\cline { 3 - 5 } Dilutions $^{\mathbf{u}}$ & ${\text { Target }(\mathbf{l o g})^{\mathbf{v}}}^{n}$ & $\mathbf{X w}^{\mathbf{w}}$ & $\mathbf{X e}^{\mathbf{x}}$ & $\mathbf{X c}^{\mathbf{y}}$ \\
\hline $10^{0}$ & 6.2024 & $26.64 \pm 0.21$ & $26.55 \pm 0.21$ & $26.24 \pm 0.25$ \\
$10^{-1}$ & 5.2024 & $29.81 \pm 0.25$ & $29.76 \pm 0.40$ & $29.99 \pm 0.24$ \\
$10^{-2}$ & 4.2024 & $32.78 \pm 0.46$ & $32.98 \pm 0.39$ & $32.96 \pm 0.28$ \\
$10^{-3}$ & 3.2024 & $36.79 \pm 0.58$ & $36.89 \pm 0.59$ & $37.04 \pm 0.60$ \\
$10^{-4}$ & 2.2024 & $39.82 \pm 0.79$ & $39.78 \pm 0.94$ & $39.89 \pm 0.89$ \\
$10^{-5}$ & 1.2024 & Undetectable & Undetectable & Undetectable \\
Mean $\Delta \mathrm{Ct}$ & $\ldots$ & 3.30 & 3.31 & 3.41 \\
\hline
\end{tabular}

${ }^{\mathrm{s}}$ The three dilution methods were water, Escherichia coli DNA at $50 \mathrm{ng} / \mathrm{\mu l}$, and plant total DNA extract at $50 \mathrm{ng} / \mu \mathrm{l}$. Regression analysis equations for each were water: $Y_{\mathrm{sw}}=14.13-0.2993 X_{\mathrm{sw}}, r^{2}=$ 0.9983 , and amplification efficiency $\left(\mathrm{AE} ; 10^{- \text {slope }}-1\right)=0.9920 ; E$. coli DNA: $Y_{\text {sd }}=14.07-0.2972 X_{\text {sd }}$, $r^{2}=0.9967$, and $\mathrm{AE}=0.9824$; and plant total DNA extract: $Y_{\mathrm{sm}}=13.49-0.2815 X_{\mathrm{sm}}, r^{2}=0.9954$, and $\mathrm{AE}=0.9121$.

${ }^{t} \mathrm{Ct}$ values of real-time PCR with different dilution media are means \pm standard deviation.

" Serial dilutions of DNA. Mean $=$ the mean Ct gradient between two 10-fold dilutions.

$\checkmark$ Target DNA copies.

${ }^{\mathrm{w}}$ Water.

${ }^{x}$ Pure DNA from E. coli $(50 \mathrm{ng} / \mu \mathrm{l})$. Total DNA was extracted from E. coli strain Mach1-T1 (Invitrogen, Carlsbad, CA).

y DNA extract from Citrus sinensis $(50 \mathrm{ng} / \mu \mathrm{l})$. Total DNA was extracted from midribs of healthy sweet orange leaves.

${ }^{\mathrm{z}}$ Amplification was stopped at 40 cycles. coat and embryo) (Table 4). Based on linear regression analysis, there were no significant differences in PCR assay accuracy $\left(R^{2}>0.99\right)$ and precision (SD of the mean $\mathrm{Ct}$ value) in detection of pathogen DNA diluted with extracts from various tissues of sweet orange. There were differences in the $\mathrm{AE}$ among plant tissues used. The $\mathrm{AE}$ for the serial dilutions of target DNA made in DNA extract from healthy peduncle was the highest and the AE with the serial dilutions of target DNA made in DNA extract from healthy leaf blades was the lowest. The difference between the highest and lowest $\mathrm{AE}$ was $10 \%$. None of the total DNA extracts containing nontarget DNA and putative PCR inhibitors from citrus plants affected the sensitivity of the realtime PCR assays. Based on the means of $\mathrm{Ct}$ values obtained at each of the serial dilutions, a universal standard curve for "plant tissues" $\left(Y_{\mathrm{ut}}\right)$ was constructed for various tissues of sweet orange. The universal regression equation for plant tissues also had a high assay accuracy $\left(R^{2}>0.99\right)$ and a high AE (0.9337).

Effect of host species on pathogen quantification. To study the effects of various citrus species on estimates of ' $\mathrm{Ca}$. L. asiaticus' populations by real-time PCR, specific standard curves were established for serial dilutions of the infected field DNA sample of total DNA extracts at 50 $\mathrm{ng} / \mu \mathrm{l}$ prepared from leaf midribs of healthy plants of nine citrus species (Table 5). All nine citrus species were greenhouse grown in Beltsville, MD. Based on linear regression analysis, there were no significant differences in PCR detection accuracy $\left(R^{2}\right.$ $>0.99$ ) and precision (SD of the mean $\mathrm{Ct}$ value) among the species used. However, there were differences in $\mathrm{AE}$ among the species tested. The real-time PCR with the serial dilutions in DNA extract from sour orange (C. auantium) had the highest $\mathrm{AE}$ and the serial dilutions in DNA extract from mandarin ( $C$. reticulata) yielded the lowest AE. The difference between the highest and lowest AE was 17\%. A universal standard curve for "species" ( $\left.Y_{\text {us }}\right)$ was constructed for different citrus species based on the mean $\mathrm{Ct}$ values obtained at each of the serial dilutions in total DNA extracts from the citrus species evaluated (Table 5). The universal regression equa-

Table 3. Estimated deviation in the quantification of target DNA in a field sample of sweet orange infected by 'Candidatus Liberibacter asiaticus' in Florida with regression equations based on absolute and relative standard curves ${ }^{\mathrm{x}}$

\begin{tabular}{lcccccc}
\hline & \multicolumn{5}{c}{ Target DNA copies in serial dilutions of an actual DNA sample } \\
\cline { 2 - 6 } Regression equation & $\mathbf{1 . 5 9 \times \mathbf { 1 0 } ^ { \mathbf { 6 } }}$ & $\mathbf{1 . 5 9 \times \mathbf { 1 0 } ^ { \mathbf { 5 } }}$ & $\mathbf{1 . 5 9 \times \mathbf { 1 0 } ^ { \mathbf { 4 } }}$ & $\mathbf{1 . 5 9 \times \mathbf { 1 0 } ^ { \mathbf { 3 } }}$ & ${\mathbf{1 . 5 9} \times \mathbf{1 0}^{\mathbf{2}}}^{\text {MAVED }^{\mathbf{z}}}$ \\
\hline$Y_{\mathrm{aw}}$ & -70.00 & -80.41 & -84.40 & -93.65 & -93.46 & $84.38 \mathrm{a}$ \\
$Y_{\text {ad }}$ & 59.12 & 0.63 & 12.58 & -44.28 & 32.08 & $29.74 \mathrm{~b}$ \\
$Y_{\text {am }}$ & 38.36 & -12.58 & -1.89 & -51.51 & 40.63 & $29.00 \mathrm{~b}$ \\
$Y_{\text {sw }}$ & 18.87 & -10.06 & 15.72 & -30.19 & -2.52 & $15.47 \mathrm{c}$ \\
$Y_{\text {sd }}$ & 17.76 & -9.43 & 18.24 & -27.67 & $15.05 \mathrm{c}$ \\
$Y_{\text {sm }}$ & -20.13 & -29.56 & 2.52 & -27.04 & 14.47 & $18.74 \mathrm{c}$ \\
\hline
\end{tabular}

${ }^{\mathrm{x}}$ Estimated deviation $=($ estimated value - standard value $) /$ standard value $\times 100$.

y Target DNA copy number was estimated based on the absolute standard curve $Y_{\mathrm{am}}=14.74-0.3174 X$ (Table 1).

${ }^{\mathrm{z}}$ MAVED $=$ mean of the absolute value of the estimated deviation. MAVEDs followed by the same letter are not significantly different $(P=0.05)$. 
tion for species had both excellent accuracy $\left(R^{2}>0.99\right)$ and $\mathrm{AE}(\mathrm{AE}=0.9413)$.

Effect of geographic location on pathogen quantification. To evaluate geographic effects on estimates of ' $\mathrm{Ca}$. L. asiaticus' populations in plant samples, total DNA extracts were obtained from midribs of healthy sweet orange plants collected from geographically different locations (Table 6). Standard curves were established for the serial dilutions of the infected field DNA sample in the healthy DNA extracts. A universal standard curve for "geographic origin" $\left(Y_{\mathrm{ug}}\right)$ was obtained for geographic locations based on the mean $\mathrm{Ct}$ values obtained at each of the serial dilutions in total DNA extracts of sweet orange leaf midribs from these locations (Table 6). No significant differences were found in PCR assay accuracy $\left(R^{2}>\right.$ 0.99) and precision (SD of the mean $\mathrm{Ct}$ values) among extracts from different geographic locations. However, the differences in PCR AE among the sweet orange leaf midrib extracts from different locations showed that the same citrus species and tissue might produce different quantity or quality of PCR inhibitors in different geographic areas. The difference between the highest $\mathrm{AE}$ and the lowest one was $17 \%$, which was similar to the differences in $\mathrm{AE}$ among the various citrus species in Table 5 .

Effect of refrigerated storage on pathogen quantification. To evaluate the effect of sample storage on estimates of ' $\mathrm{Ca}$. Liberibacter asiaticus' populations, intact leaves and chopped midribs from HLB-symptomatic material of pumelo $(C$. maxima) received from Florida were stored at $4^{\circ} \mathrm{C}$ for 10 weeks. Total DNA was extracted from the stored materials at weekly intervals. Real-time PCR of the DNA extracts showed no differences in either the $\mathrm{Ct}$ values or the estimated number of target DNA molecules (Table 7), indicating that continuous refrigerated storage of plant samples did not affect subsequent quantitative real-time PCR assays.

\section{DISCUSSION}

It has been impossible until recently to quantify the titer of the $C a$. Liberibacter spp. in host or vector tissues because none of the species have been isolated and cultured in artificial media. Fortunately, realtime PCR has become a mainstream method for quantification in microbiology. Broadly speaking, there are two approaches to estimate the quantity of target DNA molecules in a sample $(24,25,29$, 32,37). The absolute quantification method determines the copy number of a DNA template based on a standard curve established from purified target DNA of known mass and known concentration. The relative quantification method uses one experimental sample to normalize and generate estimates of the copy number of the target relative to the reference sample. Absolute standard curves usually are constructed from plasmids containing the target DNA as cloned inserts $(31,40)$. Genomic DNA $(4,15,19,41)$ or cells $(41)$ of

Table 4. Influence of DNA extracts from different tissues of sweet orange on the real-time polymerase chain reaction (PCR) detection of 'Candidatus Liberibacter asiaticus' DNA in extracts from infected pummelo

\begin{tabular}{|c|c|c|c|c|c|c|c|c|}
\hline \multirow[b]{2}{*}{ Media $^{y}$} & \multicolumn{5}{|c|}{ Cycle threshold $(\mathrm{Ct})$ values $^{\mathrm{x}}$} & \multirow[b]{2}{*}{ Linear regression } & \multirow[b]{2}{*}{$r^{2}$} & \multirow[b]{2}{*}{$\mathbf{A} \mathbf{E}^{\mathbf{z}}$} \\
\hline & 6.2024 & 5.2024 & 4.2024 & 3.2024 & 2.2024 & & & \\
\hline Peduncle & $27.02 \pm 0.30$ & $30.16 \pm 0.38$ & $33.27 \pm 0.50$ & $37.35 \pm 0.65$ & $40.24 \pm 0.88$ & $Y_{\mathrm{pd}}=14.17-0.2966 X_{\mathrm{pd}}$ & 0.9974 & 0.9797 \\
\hline Embryos & $27.16 \pm 0.32$ & $30.24 \pm 0.27$ & $33.30 \pm 0.50$ & $37.44 \pm 0.73$ & $40.75 \pm 0.97$ & $Y_{\mathrm{em}}=13.99-0.2900 X_{\mathrm{em}}$ & 0.9969 & 0.9498 \\
\hline Stem bark & $26.97 \pm 0.20$ & $30.05 \pm 0.28$ & $33.15 \pm 0.45$ & $37.37 \pm 0.58$ & $40.56 \pm 0.86$ & $Y_{\mathrm{sb}}=13.91-0.2889 X_{\mathrm{sb}}$ & 0.9967 & 0.9449 \\
\hline Root bark & $26.66 \pm 0.19$ & $29.89 \pm 0.35$ & $33.12 \pm 0.49$ & $37.22 \pm 0.70$ & $40.46 \pm 0.80$ & $Y_{\mathrm{rb}}=13.76-0.2858 X_{\mathrm{rb}}$ & 0.9981 & 0.9311 \\
\hline Fruit septum & $27.11 \pm 0.31$ & $30.22 \pm 0.34$ & $33.54 \pm 0.46$ & $37.77 \pm 0.60$ & $40.78 \pm 0.95$ & $Y_{\mathrm{fs}}=13.88-0.2858 X_{\mathrm{fs}}$ & 0.9971 & 0.9311 \\
\hline Fruit central axis & $26.49 \pm 0.26$ & $29.79 \pm 0.29$ & $33.05 \pm 0.43$ & $37.23 \pm 0.68$ & $40.43 \pm 0.87$ & $Y_{\mathrm{fa}}=13.64-0.2826 X_{\mathrm{fa}}$ & 0.9981 & 0.9169 \\
\hline Midribs & $26.24 \pm 0.25$ & $29.99 \pm 0.24$ & $32.96 \pm 0.28$ & $37.04 \pm 0.60$ & $39.89 \pm 0.89$ & $Y_{\mathrm{mi}}=13.49-0.2815 X_{\mathrm{mi}}$ & 0.9952 & 0.9120 \\
\hline Petioles & $26.68 \pm 0.22$ & $29.62 \pm 0.25$ & $33.08 \pm 0.35$ & $37.83 \pm 0.56$ & $40.21 \pm 0.84$ & $Y_{\mathrm{pt}}=13.61-0.2810 X_{\mathrm{pt}}$ & 0.9911 & 0.9098 \\
\hline Fruit peel & $26.52 \pm 0.26$ & $29.23 \pm 0.26$ & $33.18 \pm 0.34$ & $37.54 \pm 0.52$ & $40.24 \pm 0.85$ & $Y_{\mathrm{fp}}=13.46-0.2778 X_{\mathrm{fp}}$ & 0.9932 & 0.8958 \\
\hline Seed coat & $26.34 \pm 0.21$ & $29.01 \pm 0.24$ & $33.12 \pm 0.31$ & $37.28 \pm 0.50$ & $40.15 \pm 0.81$ & $Y_{\mathrm{sc}}=13.39-0.2770 X_{\mathrm{sc}}$ & 0.9941 & 0.8923 \\
\hline Locular membrane & $26.78 \pm 0.25$ & $30.03 \pm 0.30$ & $33.68 \pm 0.38$ & $37.88 \pm 0.72$ & $40.89 \pm 0.83$ & $Y_{\mathrm{lm}}=13.56-0.2766 X_{\mathrm{lm}}$ & 0.9977 & 0.8906 \\
\hline Leaf blades & $26.15 \pm 0.18$ & $29.11 \pm 0.33$ & $33.02 \pm 0.40$ & $37.12 \pm 0.64$ & $40.33 \pm 0.70$ & $Y_{\mathrm{lb}}=13.29-0.2742 X_{\mathrm{lb}}$ & 0.9972 & 0.8801 \\
\hline Universal & $26.70 \pm 0.25$ & $29.81 \pm 0.29$ & $33.16 \pm 0.41$ & $37.33 \pm 0.63$ & $40.35 \pm 0.85$ & $Y_{\mathrm{ut}}=13.79-0.2864 X_{\mathrm{ut}}$ & 0.9974 & 0.9337 \\
\hline
\end{tabular}

${ }^{\mathrm{x}} \mathrm{Ct}$ values of real-time PCR for serial dilutions are means \pm standard deviation. Ten-fold serial dilutions of the DNA sample from plants infected with ' $C a$.

Liberibacter asiaticus' in Florida were made in total DNA extracts from different tissues of healthy sweet orange. The log concentrations of the target DNA copies in the serial dilutions of the field DNA samples were estimated based on the absolute standard curve $Y_{\mathrm{am}}=14.74-0.3174 X$ (Table 1 ).

y DNA extracts used as dilution media. The concentration of DNA in extracts from plant tissues collected from healthy sweet orange were adjusted to 50 $\mathrm{ng} / \mu \mathrm{l}$ with Tris-EDTA buffer and used as diluent of the infected midrib sample prepared from Citrus maxima. Universal = universal standard curve for different tissues of sweet orange, established based on the mean $\mathrm{Ct}$ values.

${ }^{\mathrm{z}}$ PCR amplification efficiency $(\mathrm{AE})=10^{- \text {slope }}-1(15)$.

Table 5. Influence of DNA from different host plant species on real-time polymerase chain reaction (PCR) detection of 'Candidatus Liberibacter asiaticus' DNA

\begin{tabular}{|c|c|c|c|c|c|c|c|c|}
\hline \multirow[b]{2}{*}{ Media $^{y}$} & \multicolumn{5}{|c|}{ Cycle threshold $(\mathrm{Ct})$ values $^{\mathrm{x}}$} & \multirow[b]{2}{*}{ Linear regression } & \multirow[b]{2}{*}{$r^{2}$} & \multirow[b]{2}{*}{$\mathbf{A} \mathbf{E}^{\mathbf{z}}$} \\
\hline & 6.2024 & 5.2024 & 4.2024 & 3.2024 & 2.2024 & & & \\
\hline C. aurantium & $26.77 \pm 0.20$ & $30.26 \pm 0.34$ & $33.21 \pm 0.35$ & $36.55 \pm 0.80$ & $39.87 \pm 0.84$ & $Y_{\mathrm{ca}}=14.45-0.3076 X_{\mathrm{ca}}$ & 0.9995 & 1.0305 \\
\hline C. mitis & $27.06 \pm 0.30$ & $30.87 \pm 0.33$ & $33.78 \pm 0.45$ & $37.92 \pm 0.81$ & $40.24 \pm 0.88$ & $Y_{\mathrm{cm}}=14.30-0.2975 X_{\mathrm{cm}}$ & 0.9939 & 0.9838 \\
\hline C. maxima & $26.53 \pm 0.24$ & $30.05 \pm 0.30$ & $33.25 \pm 0.40$ & $37.12 \pm 0.64$ & $40.15 \pm 0.90$ & $Y_{\mathrm{pm}}=13.93-0.2912 X_{\mathrm{pm}}$ & 0.9990 & 0.9552 \\
\hline C. hystrix & $26.81 \pm 0.27$ & $29.82 \pm 0.36$ & $32.89 \pm 0.41$ & $37.06 \pm 0.77$ & $40.36 \pm 0.93$ & $Y_{\mathrm{ch}}=13.88-0.2902 X_{\mathrm{ch}}$ & 0.9965 & 0.9507 \\
\hline C. limonia & $26.79 \pm 0.25$ & $30.34 \pm 0.37$ & $33.27 \pm 0.47$ & $37.19 \pm 0.75$ & $40.64 \pm 0.85$ & $Y_{\mathrm{li}}=13.92-0.2890 X_{\mathrm{li}}$ & 0.9985 & 0.9454 \\
\hline C. paradisi & $26.98 \pm 0.26$ & $30.41 \pm 0.36$ & $33.65 \pm 0.48$ & $37.86 \pm 0.78$ & $40.75 \pm 0.91$ & $Y_{\mathrm{cp}}=13.87-0.2751 X_{\mathrm{cp}}$ & 0.9976 & 0.9280 \\
\hline C. sinensis & $26.68 \pm 0.22$ & $29.55 \pm 0.28$ & $33.16 \pm 0.38$ & $37.53 \pm 0.60$ & $40.38 \pm 0.86$ & $Y_{\mathrm{cs}}=13.61-0.2812 X_{\mathrm{cs}}$ & 0.9950 & 0.9107 \\
\hline C. limon & $26.58 \pm 0.21$ & $30.12 \pm 0.32$ & $33.56 \pm 0.44$ & $37.32 \pm 0.69$ & $40.79 \pm 0.95$ & $Y_{\mathrm{cl}}=13.65-0.2807 X_{\mathrm{cl}}$ & 0.9998 & 0.9085 \\
\hline C. reticulata & $26.35 \pm 0.23$ & $29.54 \pm 0.28$ & $32.97 \pm 0.38$ & $37.68 \pm 0.77$ & $40.66 \pm 0.89$ & $Y_{\mathrm{cr}}=13.25-0.2707 X_{\mathrm{cr}}$ & 0.9950 & 0.8651 \\
\hline Universal & $26.73 \pm 0.24$ & $30.11 \pm 0.33$ & $33.30 \pm 0.42$ & $37.36 \pm 0.73$ & $40.43 \pm 0.89$ & $Y_{\mathrm{us}}=13.87-0.2881 X_{\mathrm{us}}$ & 0.9984 & 0.9413 \\
\hline
\end{tabular}

${ }^{x} \mathrm{Ct}$ values of real-time PCR for serial dilutions are means \pm standard deviation. The log of the concentrations of the target DNA copies in the serial dilutions of the field DNA samples were estimated based on the absolute standard curve $Y_{\mathrm{am}}=14.74-0.3174 X$ (Table 1).

y DNA extracts used as dilution media. The concentration of total DNA in extracts from leaf midribs of healthy citrus plants of the species indicated were adjusted to $50 \mathrm{ng} / \mu \mathrm{l}$ with Tris-EDTA buffer and used as diluent in a ten-fold dilution series of the infected midrib sample prepared from Citrus maxima. Universal = universal standard curve for various citrus species, established based on the mean $\mathrm{Ct}$ values.

z PCR amplification efficiency $(\mathrm{AE})=10^{- \text {slope }}-1(15)$. 
known concentration also can be used to generate absolute quantification curves. Plasmid DNA standards can be used to replace genomic DNA standards because the two kinds of DNA standards yield similar standard curves (31). Side-by-side comparison between the direct use of $M y$ cobacterium cells and the use of its genomic DNA in construction of absolute standard curves showed very good correlation for quantification of the causal agent of Johne's disease in cattle (33).

For absolute quantification of $\mathrm{Ca}$. Liberibacter spp. in host plants, absolute standard curves were established using plasmid pFL136 at known concentrations. Relative standard curves were obtained from serial dilutions of an infected field DNA sample. The number of target molecules in the dilution series was estimated with the absolute standard curve. Analysis of the MAVED (Table 3) showed clearly that it was better to use the relative standard curves rather than the absolute standard curves for quantification of target DNA in the field sample infected by $C a$. Liberibacter spp. Real-time PCR for detection and quantification of foodborne pathogens also showed that it was necessary to prepare relative standard curves using the cells or DNA in the samples tested because standard curves for the same target DNA molecule varied with food samples (41).

The number of target DNA molecules of ' $\mathrm{Ca}$. Liberibacter asiaticus' in extracts of field tissue was underestimated by $84 \%$ when the absolute standard curve made from serial dilutions of the cloned plasmid standard in water $\left(Y_{\text {aw }}\right)$ was used (Table 3 ). This is because the AE of the target DNA in water (1.1878; Table 1) was significantly higher than for the field plant DNA sample in water (0.9920; Table 2). The differences in AE between the serial dilutions of the cloned plasmid (Table 1) and those of the field plant DNA samples (Table 2) could be due to the different background noises caused by the two DNA samples during fluorescence generation of the real-time PCR reactions (1).

Amplification of the target occurred at 10 copies per reaction when diluted in water but not when diluted with nontarget E. coli DNA at $50 \mathrm{ng} / \mu \mathrm{l}$, and the $\mathrm{AE}$ for the plasmid target was decreased $10 \%$ by the nontarget $E$. coli DNA (Table 1). However, when the naturally infected plant extract was used as the source of target DNA, reduction of AE by nontarget E. coli DNA was not observed (Table 2). This might result from the effect of the nontarget E. coli DNA being overshadowed by the host effects from the nontarget plant DNA and PCR inhibitors present in the plant extract. The PCR inhibitors in DNA extracts from citrus plants have been documented $(9,18)$. These inhibitors did not affect the sensitivity of real-time PCR for the detection and identification of pathogens in citrus plants when the extracts were prepared with an optimized protocol $(19,20)$.

A range of PCR amplification efficiencies of the pumelo-derived Ca. Liberibacter spp. target DNA were observed when DNA from various tissues of sweet orange was the diluent (0.9797 to 0.8801; Table 4), when DNA from different citrus species was evaluated as diluent (1.0305 to 0.8651 ; Table 5), and when the diluent was derived from citrus from geographically different locations (1.0384 to 0.8681; Table 6). These differences in PCR AE might be due to differences in quantity and quality of inhibitory compounds that remain in the DNA extract following purification. Three "universal linear regression" equations, have been established to optimize the assay for various tissues $\left(Y_{\mathrm{ut}}\right.$; Table 4$)$, different citrus species ( $Y_{\text {us }}$; Table 5) and geographically different locations ( $Y_{\text {ug }}$; Table 6), respectively. These universal linear regression equations were very similar and no significant differences in the slopes or PCR AE among the three universal linear regression equations were found. Therefore a "grand universal regression equation" for citrus extracts, $Y=13.82$ $0.2866 X$, where $Y$ is the $\log$ of the target copy number and $X$ is the $\mathrm{Ct}$ of the assay, was made by combining the three universal standard curves. This grand universal linear regression accommodates all of the

Table 7. Influence of storage of plant samples at $4^{\circ} \mathrm{C}$ prior to estimating by real-time polymerase chain reaction (PCR) the 'Candidatus Liberibacter asiaticus' populations in tissues from Citrus maxima trees naturally infected in Florida

\begin{tabular}{|c|c|c|}
\hline $\begin{array}{l}\text { Material } \\
\left(\text { weeks) }{ }^{x}\right.\end{array}$ & $\begin{array}{c}\mathrm{Ct} \\
\text { values }^{\mathrm{y}}\end{array}$ & $\begin{array}{c}\text { Molecules } \\
\left(\times \mathbf{1 0}^{6}\right)^{\mathrm{z}}\end{array}$ \\
\hline \multicolumn{3}{|c|}{ Excised midribs } \\
\hline 1 & 24.68 & 3.49 \\
\hline 2 & 24.26 & 4.58 \\
\hline 3 & 24.89 & 3.04 \\
\hline 4 & 24.36 & 4.29 \\
\hline 5 & 24.58 & 3.72 \\
\hline 6 & 24.76 & 3.31 \\
\hline 7 & 24.86 & 3.10 \\
\hline 8 & 24.52 & 3.87 \\
\hline 9 & 24.63 & 3.60 \\
\hline 10 & 24.59 & 3.70 \\
\hline \multicolumn{3}{|c|}{ Whole leaves } \\
\hline 1 & 25.24 & 2.43 \\
\hline 2 & 24.88 & 3.06 \\
\hline 3 & 25.04 & 2.76 \\
\hline 4 & 24.55 & 3.79 \\
\hline 5 & 24.87 & 3.08 \\
\hline 6 & 25.12 & 2.62 \\
\hline 7 & 25.22 & 2.46 \\
\hline 8 & 24.46 & 4.02 \\
\hline 9 & 25.47 & 2.09 \\
\hline 10 & 25.35 & 2.26 \\
\hline
\end{tabular}

x Plant material and storage time.

${ }^{y}$ Mean cycle threshold $(\mathrm{Ct})$ values were obtained with triplicate assays for each DNA extract by multiplex real-time PCR using the primer-probe set HLBaspr specific to ' $\mathrm{Ca}$. Liberibacter asiaticus' and the internal positive control primer-probe set COXfpr (19).

${ }^{z}$ Estimated number of target DNA molecules per $1 \mu \mathrm{l}$ per reaction were obtained by the grand universal regression equation for citrus extracts, $Y=13.82-02866 X$. Out of a $200-\mu \mathrm{l}$ extract volume, $1 \mu \mathrm{l}$ was used per assay and $200 \mathrm{mg}$ of tissue was used to make the extract. Therefore, the concentration of target DNA per gram of plant tissue is obtained by multiplying the numbers in this column by 1,000 .

Table 6. Influence of the geographic origin of DNA extracts from midribs of healthy sweet orange on real-time polymerase chain reaction (PCR) detection of 'Candidatus Liberibacter asiaticus' DNA in extracts from infected pummelo tissue

\begin{tabular}{|c|c|c|c|c|c|c|c|c|}
\hline \multirow[b]{2}{*}{ Media $^{y}$} & \multicolumn{5}{|c|}{ Cycle threshold $(\mathrm{Ct})$ values $^{\mathrm{x}}$} & \multirow[b]{2}{*}{ Linear regression } & \multirow[b]{2}{*}{$r^{2}$} & \multirow[b]{2}{*}{$\mathbf{A} \mathbf{E}^{\mathbf{z}}$} \\
\hline & 6.2024 & 5.2024 & 4.2024 & 3.2024 & 2.2024 & & & \\
\hline Nelspruit, South Africa & $26.87 \pm 0.24$ & $30.82 \pm 0.35$ & $33.64 \pm 0.41$ & $36.94 \pm 0.76$ & $39.93 \pm 0.85$ & $Y_{\mathrm{sa}}=14.60-0.3093 X_{\mathrm{sa}}$ & 0.9971 & 1.0384 \\
\hline São Paulo, Brazil & $26.69 \pm 0.25$ & $30.74 \pm 0.40$ & $33.76 \pm 0.43$ & $37.33 \pm 0.80$ & $40.15 \pm 0.92$ & $Y_{\mathrm{br}}=14.23-0.2974 X_{\mathrm{br}}$ & 0.9966 & 0.9834 \\
\hline Puerto Rico, U.S.A. & $26.82 \pm 0.21$ & $30.75 \pm 0.35$ & $33.73 \pm 0.45$ & $37.23 \pm 0.71$ & $40.88 \pm 0.87$ & $Y_{\mathrm{pr}}=13.97-0.2886 X_{\mathrm{pr}}$ & 0.9986 & 0.9436 \\
\hline Hawaii, U.S.A. & $26.50 \pm 0.26$ & $30.55 \pm 0.31$ & $33.47 \pm 0.46$ & $37.56 \pm 0.72$ & $40.46 \pm 0.84$ & $Y_{\mathrm{hw}}=13.81-0.2853 X_{\mathrm{hw}}$ & 0.9967 & 0.9289 \\
\hline Florida, U.S.A. & $26.68 \pm 0.22$ & $29.55 \pm 0.28$ & $33.16 \pm 0.38$ & $37.53 \pm 0.60$ & $40.38 \pm 0.86$ & $Y_{\mathrm{fl}}=13.61-0.2812 X_{\mathrm{fl}}$ & 0.9950 & 0.9107 \\
\hline Texas, U.S.A. & $26.25 \pm 0.20$ & $29.78 \pm 0.29$ & $33.18 \pm 0.42$ & $37.48 \pm 0.65$ & $40.55 \pm 0.89$ & $Y_{\mathrm{tx}}=13.39-0.2748 X_{\mathrm{tx}}$ & 0.9980 & 0.8829 \\
\hline Maryland, U.S.A. & $26.54 \pm 0.19$ & $29.98 \pm 0.26$ & $32.87 \pm 0.50$ & $37.67 \pm 0.68$ & $40.92 \pm 0.90$ & $Y_{\mathrm{md}}=13.36-0.2728 X_{\mathrm{md}}$ & 0.9943 & 0.8741 \\
\hline Georgia, U.S.A. & $26.44 \pm 0.25$ & $30.08 \pm 0.27$ & $32.66 \pm 0.40$ & $37.87 \pm 0.78$ & $40.79 \pm 0.91$ & $Y_{\mathrm{ga}}=13.31-0.2714 X_{\mathrm{ga}}$ & 0.9902 & 0.8681 \\
\hline Universal & $26.73 \pm 0.24$ & $30.11 \pm 0.33$ & $33.30 \pm 0.42$ & $37.36 \pm 0.73$ & $40.43 \pm 0.89$ & $Y_{\mathrm{ug}}=13.79-0.2852 X_{\mathrm{ug}}$ & 0.9980 & 0.9284 \\
\hline
\end{tabular}

${ }^{x} \mathrm{Ct}$ values of real-time PCR for serial dilutions are means \pm standard deviation. The log concentrations of the target DNA copies in the serial dilutions of the field DNA samples were estimated based on the absolute standard curve $Y_{\text {am }}=14.74-0.3174 X$ (Table 1).

${ }^{y}$ DNA extracts used as dilution media. The concentration of total DNA in extracts from leaf midribs of healthy sweet orange plants from the origins indicated were adjusted to $50 \mathrm{ng} / \mu \mathrm{l}$ with Tris-EDTA buffer and used as diluent in a ten-fold dilution series of the infected midrib sample prepared from Citrus maxima . Universal $=$ universal standard curve for different locations, established based on the mean Ct values.

${ }^{\mathrm{z}}$ PCR amplification efficiency $(\mathrm{AE})=10^{- \text {slope }}-1(15)$. 
sample effects on quantification of $\mathrm{Ca}$. Liberibacter spp. in citrus plants that we have documented to date.

An example of population estimates in citrus samples using the grand universal linear regression is shown in Table 7. The concentration of ' $\mathrm{Ca}$. Liberibacter asiaticus' in symptomatic leaves of $C$. maxima could be as high as up to $2.5 \times 10^{9}$ copies per gram of midrib. This number may be lower, because 16S rDNA was the target DNA and the number of the 16S rDNA operons per cell of $\mathrm{Ca}$. Liberibacter spp. is unknown, but could be greater than 1 . The actual bacterial population would be the target DNA concentration divided by the copy number of the $16 \mathrm{~S}$ rDNA operon per cell.

Based on the cutoff set up for the grand universal regression line, the low detection limit of the real-time PCR used in this study was $2.27 \times 10^{2}$ copies of $16 \mathrm{~S}$ rDNA from $\mathrm{Ca}$. Liberibacter spp. per reaction. This means that the 16S rDNA copy number must be greater than $2.27 \times 10^{5}$ per gram of fresh tissues for the real-time PCR assay to generate a positive result and quantify the pathogen in the sample. The real-time PCR is at least 100 -fold more sensitive than conventional PCR for detection of $\mathrm{Ca}$. Liberibacter spp. in citrus plants $(19,20,22,40)$. Therefore, the target DNA concentration should be at least 2.27 $\times 10^{7}$ per gram of fresh tissues for conventional PCR to be able to detect the pathogen in citrus plant samples. The detection threshold of the target DNA could be increased as much as 10-fold for both standard format and real-time PCR assays by eluting the DNA in a smaller volume of TE buffer at the end of the extraction protocol. This optimized detection threshold for conventional PCR is $2.27 \times 10^{6}$, which is very close to the bacterial population threshold for symptom development (19), and the potential exists for routine detection of $C a$. Liberibacter spp. in nonsymptomatic citrus tissues by using the realtime PCR method.

Accurate quantification of pathogen populations is fundamental to all aspects of plant pathology. The systematic and quantitative evaluation of sample effects from various plant tissues, different citrus species, and geographically different planting locations on the accuracy and efficiency of real-time PCR demonstrates the importance of carefully matching standards to test samples for quantification. The validated multiplex TaqMan real-time PCR with the grand universal standard regression equation to account for differences in plant samples promises to be a useful tool for study on population biology of the pathogen and for epidemiology and control strategy of the disease. A fully validated and reliable assay for $C a$. Liberibacter spp. also is essential for efforts to manage the disease by both regulatory agencies and industry. The demonstration herein that long-term storage of plant samples at $4^{\circ} \mathrm{C}$ prior to extraction does not affect subsequent HLB real-time PCR results will facilitate the use of this assay for both research and regulatory efforts.

\section{ACKNOWLEDGMENTS}

This research is part of the project 71681V7R01 financed by the USDA-APHIS-PPQ. We thank A. J. Ayres and D. C. Teixeira, Fundecitrus, Araraquara, São Paulo, Brazil, T. Schubert, Department of Plant Industry, Gainesville, FL, and T. Gottwald, USDA-ARS, Ft. Pierce, FL for providing DNA extracts and plant materials.

\section{LITERATURE CITED}

1. Adams, P. S. 2006. Data analysis and reporting, pages 39-62 in: Real-Time PCR. M. Tevfik Dorak, ed. Taylor \& Francis, New York.

2. Bové, J. M. 2006. Huanglongbing: a destructive, newly-emerging, century-old disease of citrus. J. Plant Pathol. 88:7-37.

3. Chen, Q. 1943. A report of a study on yellow shoot of citrus in Chapshan. New Agric. Q. Bull. 3:143-175.

4. Costa, C., Vidaud, D., Olivi, M., BartDelabesse, E., Vidaud, M., and Bretagne, S. 2001. Development of two real-time quantitative TaqMan PCR assays to detect circulating Aspergillus fumigatus DNA in serum. J. Microbiol. Methods 44:263-269.

5. da Graça, J. V., and Korsten, L. 2004. Citrus huanglongbing: review, present status and future strategies. Pages 229-245 in: Diseases of Fruits and Vegetables, Vol. 1. S. A. M. H. Naqvi, ed. Kluwer Academic, Dordrecht, The Netherlands.

6. Garnier, M., and Bové, J. M. 1993. Citrus greening disease. Pages 212-219 in: Proc. 12th Conf. Int. Organ. Citrus Virol. IOCV, Riverside, CA.

7. Gottwald, T. R., Aubert, B., and Zhao, X. Y. 1989. Preliminary analysis of citrus greening (Huanglongbing) epidemics in the People's Republic of China and French Reunion Island. Phytopathology 79:687-693.

8. Halbert, S. E., and Manjunath, K. L. 2004. Asian citrus psyllids (Sternorrhycha: Psyllidae) and greening disease of citrus: a literature review and assessment of risk in Florida. Fla. Entomol. 87:330-353

9. Hartung, J. S., Daniel, J. F., and Pruvost, O. P. 1993. Detection of Xanthomonas campestris pv. citri by the polymerase chain reaction method. Appl. Environ. Microbiol. 59:1143-1148.

10. Higuchi, R., Fockler, C., Dollinger, G., and Watson, R. 1993. Kinetic PCR analysis: realtime monitoring of DNA amplification reactions. Biotechnology (NY) 11:1026-1030.

11. Hocquellet, A., Toorawa, P., Bové, J. M., and Garnier, M. 1999. Detection and identification of the two Candidatus Liberibacter species associated with citrus huanglongbing by PCR amplification of ribosomal protein genes of the $\beta$ operon. Mol. Cell. Probes 13:373-379.

12. Hung, T. H., Wu, M. L., and Su, H. J. 1999. Development of a rapid method for the diagnosis of citrus greening disease using the polymerase chain reaction. J. Phytopathol. 147:599-604

13. Jagoueix, S., Bove, J. M., and Garnier, M. 1994. The phloem-limited bacterium of greening disease of citrus is a member of the alpha subdivision of the Proteobacteria. Int. J. Syst. Bacteriol. 44:379-386.

14. Jagoueix, S., Bové, J. M., and Garnier, M. 1996. PCR detection of the two 'Candidatus' Liberobacter species associated with greening disease of citrus. Mol. Cell. Probes 10:43-50.

15. Klein, D., Janda, P., Steinborn, R., Muller, M., Salmons, B., and Gunzberg, W. H. 1999. Proviral load determination of different feline immunodeficiency virus isolates using real- time polymerase chain reaction: influence of mismatches on quantification. Electrophoresis 20:291-299.

16. Klerks, M. M., Zijlstra, C., and van Bruggen, A. H. C. 2004. Comparison of real-time PCR methods for detection of Salmonella enterica and Escherichia coli $0157: \mathrm{H7}$, and introduction of a general internal amplification control. J. Microbiol. Methods 59:337-349.

17. Laflèche, D., and Bové, J. M. 1970. Mycoplasmes dans les agrumes atteints de "greening", de stubborn, on des maladies similaires. Fruits 25:455-465.

18. Li, W., Brlansky, R. H., and Hartung, J. S. 2006. Amplification of DNA of Xanthomonas axonopolis pv. citri from historic citrus canker herbarium specimens. J. Microbiol. Methods 65:237-246.

19. Li, W. Hartung, J. H., and Levy, L. 2006. Quantitative real-time PCR for detection and identification of Candidatus Liberibacter species associated with citrus huanglongbing. J. Microbiol. Methods 66:104-115.

20. Li, W., Hartung, J. S., and Levy, L. 2007. Evaluation of DNA amplification methods for improved detection of "Candidatus Liberibacter species" associated with citrus huanglongbing. Plant Dis. 91:51-58.

21. Li, W., Pria, W. D., Jr., Lacava, P. M., Qin, X. and Hartung, J. S. 2003. Presence of Xylella fastidiosa in sweet orange fruit and seeds and its transmission to seedlings. Phytopathology 93:953-958.

22. Liao, X. L., Zhu, S. F., Zhao, W. J., Luo, K., Qi, Y. X., Chen, H. Y., He, K., and Zhu, X. X. 2004. Cloning and sequencing of citrus huanglongbing pathogen 16S rDNA and its detection by real-time fluorescent PCR. J. Agric. Biotechnol. 12:80-80.

23. Liu, L. Cai, X., Zhang, X., Gao, Q., Yang, X. Zheng, Z., Luo, M., and Huang, X. 2006. Rea time PCR using Taqman and SYBR Green for detection of Enterobacter sakazakii in infant formula. J. Microbiol. Methods 65:21-31.

24. Livak, K. J., and Schmittgen, T. D. 2001 Analysis of relative gene expression data using real-time quantitative PCR and the $2^{-\mathrm{CT}}$ method. Methods 25:402-408.

25. Machay, I. M., Arden, K. E., and Nitsche, A. 2002. Survey and summary/real-time PCR in virology. Nucleic Acids Res. 30:1292-1305.

26. Martinez, A. L., and Wallace, J. M. 1967. Citrus leaf-mottle-yellows disease in the Philippines and transmission of the causal virus by the psyllid, Diaphorina citri. Plant Dis. Rep. 51:692-695.

27. McClean, A. P. D., and Oberholzer, P. C. J. 1965. Citrus psylla, a vector of the greening disease of sweet orange. S. Afr. J. Agric. Sci. 8:287-298.

28. Murray, M. G., and Thompson, W. F. 1980. Rapid isolation of high molecular weight plant DNA. Nucleic Acids Res. 8:4321-4325.

29. Nonnenmacher, C., Dalpke, A., Mutters, R., and Heeg, K. 2004. Quantitative detection of periodonto pathogens by real-time PCR. J. Microbiol. Methods 59:117-125.

30. Okuda, M., Matsumoto, M., Tanaka, Y., Subandiyah, S., and Iwanami, T. 2005. Characterization of the tufB-secE-nusG-rplKAJLrpo $\mathrm{B}$ gene cluster of the citrus greening organism and detection by loop-mediated isothermal amplification. Plant Dis. 89:705-711.

31. Palaniappan, R. U. M., Chang, Y. F., Chang, C. F., Pan, M. J., Yang, C. W., Harpending, P., McDonough, S. P., Dubovi, E., Divers, T., Qu, J., and Roe, B. 2005. Evaluation of lig-based conventional and real-time PCR for detection of pathogenic leptospires. Mol. Cell. Probes 19:111-117.

32. Peirson, S. N., Butler, J. N., and Foster, R. G. 2003. Experimental validation of novel and conventional approaches to quantitative real-time PCR data analysis. Nucleic Acids 
Res. 31:e73. Online.

33. Ravva, S. V., and Stanker, L. H. 2005. Realtime quantitative PCR detection of Mycobacterium avium subsp. paratuberculosis and differentiation from other mycobacteria using SYBR green and Taqman assays. J. Microbiol. Methods 63:305-317.

34. Roistacher, C. N. 1991. Greening. Pages 35-45 in: Techniques for Biological Detection of Specific Citrus Graft Transmissible Diseases. FAO, Rome.

35. Rousselon, N., Delgenes, J.-P., and Godon, J.J. 2004. A new real time PCR (Taq Man PCR) system for detection of the $16 \mathrm{~S}$ rDNA gene associated with fecal bacteria. J. Microbiol. Methods 59:15-22.

36. Schwarz, R. E. 1968. Indexing of greening and exocortis through fluorescent marker substances. Pages 118-124 in: Proc. 4th Conf. Int Organ. Citrus Virol. University of Florida, Gainesville.

37. Smits, T. H. M., Devenoges, C., Szynalski, K., Maillard, J., and Holliger, C. 2004. Development of a real-time PCR method for quantification of the three genera Dehalobacter, Dehalococcoides, and Desulfitobacterium in microbial communities. J. Microbiol. Methods 57:369-378.

38. Teixiera, D. C., Saillard, C., Eveillard, S Danet, J. L., Ayres, A. J., and Bové, J.M. 2005. Candidatus Liberibacter americanus sp. nov., associated with citrus huanglongbing (greening disease) in São Paulo, Brazil. Int. J. Syst. Bacteriol. 55:1857-1862.
39. Tian, Y., Ke, S., and Ke, C. 1996. Polymerase chain reaction for detection and quantification of Liberobacter asiaticum, the bacterium associated with huanglongbing (greening) of citrus in China. Pages 252-257 in: Proc. 13th Conf Int. Organ. Citrus Virol. IOCV, Riverside, CA.

40. Wang, Z., Yin, Y., Hu, H., Yuan, Q., Peng, G., and Xia, Y. 2006. Development and application of molecular-based diagnosis for 'Candidatus Liberibacter asiaticus', the causal pathogen of citrus huanglongbing. Plant Pathol. 55:630638.

41. Wolffs, P., Norling, B., and Radstrom, P. 2005 Risk assessment of false-positive quantitative real-time PCR results in food, due to detection of DNA originating from dead cells. J. Microbiol. Methods 60:315-323. 